\title{
Caproic Acid Metabolism and the Production of 2-Pentanone and Gluconic Acid by Aspergillus niger
}

\author{
By H. L. LEWIS* \\ Department of Biology, Texas Tech University, Lubbock, Texas 79409, U.S.A.
}

(Accepted for publication 6 July 1970)

\begin{abstract}
SUMMAR Y
Vegetative hyphae of Aspergillus niger rapidly converted caproic acid to 2-pentanone whereas germinating spores carried out the transformation slowly and ungerminated spores not at all. Glucose stimulated ketone production by germinating spores, but suppressed it in hyphae; the degree of stimulation and suppression varied with glucose concentration. This explains earlier reports that spores but not vegetative hyphae convert fatty acids to methyl ketones, since hyphae were earlier tested with high sugar concentrations, conditions where ketone formation was inhibited. Glucose disappeared from cultures containing caproate even though ketone production was inhibited, and glucose disappearance was paralleled by gluconic acid accumulation in the medium. These findings suggest that free fatty acids may play an important role in the regulation of metabolic pathways in A. niger.
\end{abstract}

\section{INTRODUCTION}

Some filamentous fungi produce methyl ketones from fatty acids (Stärkle, 1924; Stokoe, 1928; Acklin, 1929). The process, in which the methyl ketone formed is one carbon atom shorter than the fatty acid substrate, is specific, and fatty acids longer than 14 carbon atoms are not attacked (Thaler \& Stählin, I949).

Gehrig \& Knight (1958) reported that spores of Penicillium roqueforti, but not vegetative hyphae, were able to convert fatty acids into methyl ketones. Franke, Platzeck \& Eichorn (1962) reported that vegetative hyphae of Aspergillus niger could not form methyl ketones from fatty acids, whereas spores carried out the transformation very efficiently. The process is widespread among filamentous fungi as indicated by the work of Franke \& Heinen (1958), who found that 30 out of 38 fungi tested converted fatty acids into methyl ketones, and Gehrig \& Knight (I96I) who found that 9 out of the II Aspergillus species and 9 out of the 12 Penicillium species tested also carried out the transformation. Both these reports, however, indicated that members of the Mucorales were unable to produce significant amounts of methyl ketones from fatty acids.

Lawrence (1966, 1967) reported that both oxygen uptake and methyl ketone production by spores of Penicillium roqueforti were greatly increased by certain sugars and amino acids. He interpreted this to mean that these compounds were readily oxidized to yield either energy or metabolic products essential for activation of dormant spores.

The present study establishes that vegetative hyphae of Aspergillus niger rapidly

* Present Address: Department of Molecular and Quantum Biology, University of Tennessee Medical Units, Memphis, Tennessee, 38103 , U.S.A. 
convert caproic acid to 2-pentanone, while germinating spores carry out the transformation more slowly, and examines the relationship of the process to glucose catabolism.

\section{METHODS}

Stock cultures. Aspergillus niger van Tieghem was isolated from old caproic acid solutions which had a strong ketone odour. A single spore isolate was obtained by dilution and plating on Czapek's solution agar supplemented with $0 . \mathrm{I} \%$ yeast extract (Difco). Stock cultures were subsequently maintained on this medium.

Production of spores and vegetative hyphae. A medium of the following composition $(\%, \mathrm{w} / \mathrm{v})$ was employed: D-glucose, 4.0 ; yeast extract, $0.5 ;$ Neopeptone (Difco), $\mathrm{I} \cdot \mathrm{O}$. Excellent sporulation was obtained on slants (Difco Bacto agar, $\mathrm{I} \cdot 5 \%$, w/v) of this medium after 4 to 5 days incubation at $30^{\circ}$. The spores were harvested by adding $10 \mathrm{ml}$. sterile $0.85 \% \mathrm{NaCl}$ to the slant and rubbing the surface with a stiff inoculating needle. The spore suspension was adjusted to $\mathrm{I} \times \mathrm{IO}^{9} \mathrm{spores} / \mathrm{ml}$. and $5 \mathrm{ml}$. of this suspension were added to each experimental flask. For experiments with vegetative hyphae, spores were obtained as described above, the spore suspension adjusted to $5 \times 10^{7}$ spores $/ \mathrm{ml}$. and $\mathrm{I} \cdot 0 \mathrm{ml}$. of the suspension added to $50 \mathrm{ml}$. liquid medium in $250 \mathrm{ml}$. Erlenmeyer flasks. These flasks were incubated at $30^{\circ}$ on a rotary shaker (New Brunswick Scientific Co., Psychrotherm) at I $80 \mathrm{rev} . / \mathrm{min}$. After $24 \mathrm{~h}$. the vegetative hyphae were harvested, washed three times by centrifugation and resuspended in sterile $0.85 \% \mathrm{NaCl}$ under aseptic conditions. The hyphal density was adjusted to $230 \mu \mathrm{l}$. packed mycelium $/ \mathrm{ml}$. suspension by either removal or addition of sterile $\mathrm{NaCl}(0.85 \%)$ solution (Conway \& Downey, 1950). Ten $\mathrm{ml}$. hyphal suspension were used as an inoculum for each experimental flask.

Experiments on caproate utilization and 2-pentanone production. Experiments were carried out with the following solution $(\%, \mathrm{w} / \mathrm{v})$ : caproic acid, $0.5 ; \mathrm{NaNO}_{3}, 0.2$; $\mathrm{K}_{2} \mathrm{HPO}_{4}, 0 . \mathrm{I} ; \mathrm{KCl}, 0.05 ; \mathrm{MgSO}_{4} .7 \mathrm{H}_{2} \mathrm{O}$, 0.00r; distilled water). This basal solution was supplemented with $0.0 \mathrm{I}, 0 . \mathrm{I}, 0.5$ and $\mathrm{I} \cdot 0 \% \mathrm{D}$-glucose, adjusted to a final $\mathrm{pH}$ of 6.9 with $0 . \mathrm{I} \mathrm{N}-\mathrm{KOH}$, and IIO ml. of each formulation including unsupplemented solution, placed in $500 \mathrm{ml}$. Erlenmeyer flasks. These solutions and culture media were sterilized in an autoclave at $12 \mathrm{I}^{\circ}$ for $\mathrm{I} 5 \mathrm{~min}$.

Both spores and vegetative hyphae were incubated on a reciprocating shaker (Eberbach) at $28 \pm 2^{\circ}$ and 100 strokes/min. for $98 \mathrm{~h}$. Four ml. samples were removed when required.

Analytical methods. 2-Pentanone and caproic acid were determined by gas-liquid chromatography in an Aerograph model A-600-D chromatograph equipped with a hydrogen flame ionization detector and a Leeds and Northrup Speedomax $\mathrm{H}$ recorder. The carrier gas was nitrogen flowing at $25 \mathrm{ml}$./min. The detector was operated at the same temperatures as the column, since it was mounted in the column oven.

2-Pentanone was resolved on a $5 \mathrm{ft} \times \frac{1}{8}$ in. stainless steel column containing as a stationary phase $20 \%$ phenyl diethanolamine succinate on Chromosorb W (acidwashed and treated with dimethyl-dichlorosilane, DMCS). The column was operated at $100^{\circ}$ and the injector block at $150^{\circ}$. A sample of the culture fluid was introduced on to the column by flash vaporization, and amounts of 2-pentanone determined by comparing peak heights with those for pure 2-pentanone standards. Caproic acid was resolved on a $5 \mathrm{ft} \times \frac{1}{8}$ in. stainless steel column containing as a stationary phase $10 \%$ 
FFAP (Varian Aerograph Corp.) on Chromosorb W, acid-washed and DMCS-treated. The column was operated at $175^{\circ}$ and the injector block at $225^{\circ}$. A sample of the culture fluid was introduced on to the column by flash vaporization, and amounts of caproic acid determined by comparing the product of the peak height and its width at half height with the values obtained for pure caproic acid standards.

After ketone and fatty acid analyses were complete, the remaining culture fluids were evaporated to dryness in a flash evaporator at $90^{\circ}$, dissolved in distilled water and their sugar contents determined by the method of Folin \& Malmros (I929).

Oxygen uptake measurements were made with a constant volume respirometer (Braun Instrument Co.) using standard manometric techniques (Umbreit, Burris \& Stauffer, 1964). Three ml. samples from the ketones production media were added to Warburg vessels containing $0.1 \mathrm{ml}$. of $20 \% \mathrm{KOH}$ in the centre wells, oxygen uptake was measured over $I \mathrm{~h}$. at $30^{\circ}$. Dry weights were then determined for each sample.

Gluconic and citric acids in culture fluids were detected by paper chromatography (Koepsell, Stodola \& Sharpe, 1952). Quantitative estimation of gluconic acid from paper chromatograms was done as described by Fisher, Parsons \& Holmes (I949).

\section{RESULTS}

Spore preparations of Aspergillus niger lacking glucose converted caproic acid to 2-pentanone at a low rate and did not yield detectable ketone until after 50 h. (Fig. I). When glucose was added to the basal medium, 2-pentanone production was stimulated in proportion to the amount of sugar added (Fig. I), and it commenced much earlier although none was produced before $12 \mathrm{~h}$. The onset of ketone formation was correlated with the emergence of germ tubes. Ungerminated spores were bound very tightly to hyphae and to germ tubes, indicating that spores differed in surface charge from the other two forms.

Vegetative hyphae produced 2-pentanone from caproic acid at a rapid rate, yielding detectable ketone after $3 \mathrm{~h}$. Addition of glucose to the basal medium, except in very small amounts, caused a suppression of ketone production in proportion to the amount of glucose added (Fig. 2).

Spore preparations did not utilize detectable quantities of caproate until germination had occurred (Fig. 3). Glucose greatly stimulated caproate disappearance, which paralleled 2-pentanone formation. On the other hand, vegetative hyphae utilized caproate immediately, the utilization was suppressed by the addition of glucose (Fig. 4). This suppression paralleled the depression of 2-pentanone production.

Manometric measurements showed that large amounts of $\mathrm{O}_{2}$ were taken up by vegetative hyphae in the presence of caproate alone, and in the presence of caproate and $\mathrm{O} . \mathrm{O} \mathrm{I}$ or $\mathrm{O} \cdot \mathrm{I} \%$ glucose (Fig. 6). At higher glucose concentrations $(0.5, \mathrm{I} \cdot 0 \%) \mathrm{O}_{2}$ uptake was drastically reduced after $12 \mathrm{~h}$. (Fig. 6). In all instances the initial rate of $\mathrm{O}_{2}$ uptake was increased by glucose. Spore preparations did not begin $\mathrm{O}_{2}$ uptake until after $\mathrm{I} 2 \mathrm{~h}$. and the rate of $\mathrm{O}_{2}$ uptake was proportional to the amount of glucose added (Fig. 5). The initial lag in $\mathrm{O}_{2}$ uptake coincided with the time required for germination of spores.

The $\mathrm{pH}$ values of spore cultures, with and without added glucose, increased steadily (Fig. 7). At low glucose concentrations the $\mathrm{pH}$ values of vegetative hyphal cultures also increased, but decreased at higher glucose concentrations (Fig. 8). The drop in 
$\mathrm{pH}$ values coincided with the suppression of fatty acid utilization and ketone production and the decrease in respiratory activity. The $\mathrm{pH}$ of both spore and hyphal cultures containing $\mathrm{I} \%$ glucose but no caproate fell rapidly owing to accumulation of organic acids (Fig. 7, 8).

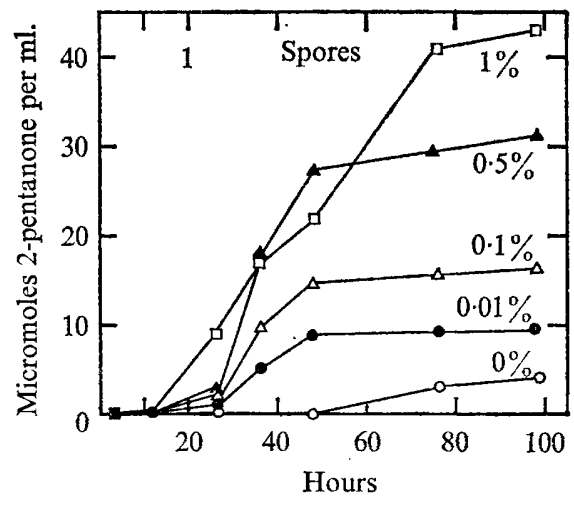

Fig. I

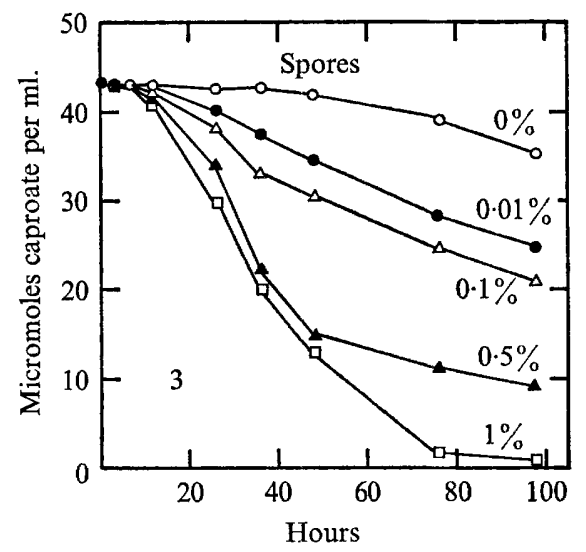

Fig. 3

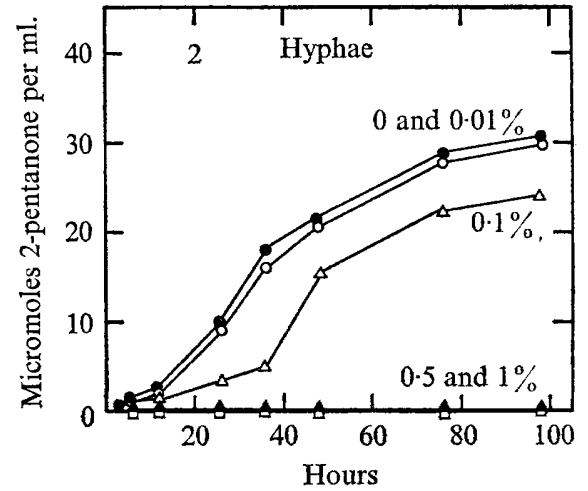

Fig. 2

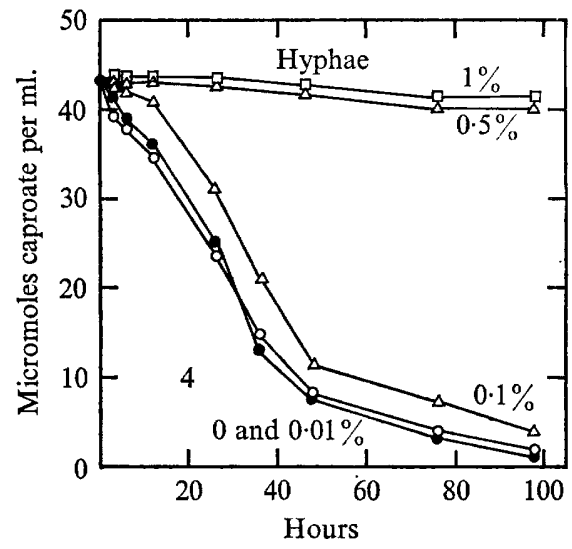

Fig. 4

Fig. I to 4. Effect of glucose concentration on 2-pentanone production (Fig. I, 2) and caproate utilization (Fig. 3, 4) by spore and hyphal cultures of Aspergillus niger containing $0.5 \%$ caproate. No glucose, $\mathrm{O}-\mathrm{O} ; 0.01 \%$ glucose, $-0 ; 0.1 \%$ glucose, $\triangle-\triangle ; 0.5 \%$ glucose, $\mathbf{A}-\mathbf{\Delta} ; \mathbf{1} \cdot 0 \%$ glucose, $\square-\square$.

Both spore and vegetative hyphal cultures containing caproate utilized glucose, but the latter utilized considerably more than the former. With $\mathrm{I} \cdot 0 \%$ glucose, vegetative hyphae utilized $25 \%$ of the sugar during the first $26 \mathrm{~h}$. with the $Q_{\mathrm{o}_{2}}$ never exceeding 4 .

Hyphal cultures with caproate but with glucose absent or in low concentrations did not accumulate detectable quantities of gluconic acid. At higher glucose concentrations gluconic acid accumulated in the culture fluid. The quantity of gluconic acid present increased with time of incubation and increasing glucose concentration (Fig. 9). Vegetative hyphal cultures with $\mathrm{I} \cdot 0 \%$ glucose but no caproate accumulated gluconic acid during the first $\mathrm{I} 2 \mathrm{~h}$. and utilized it during the next $24 \mathrm{~h}$. (Fig. 9). Spore cultures never accumulated detectable quantities of gluconic acid. 


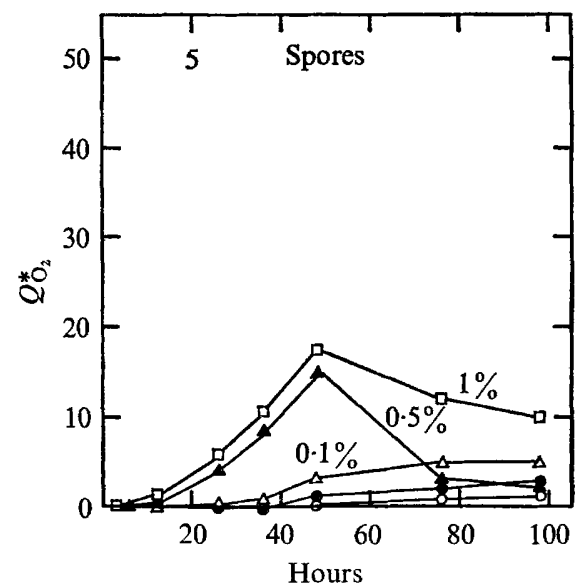

Fig. 5

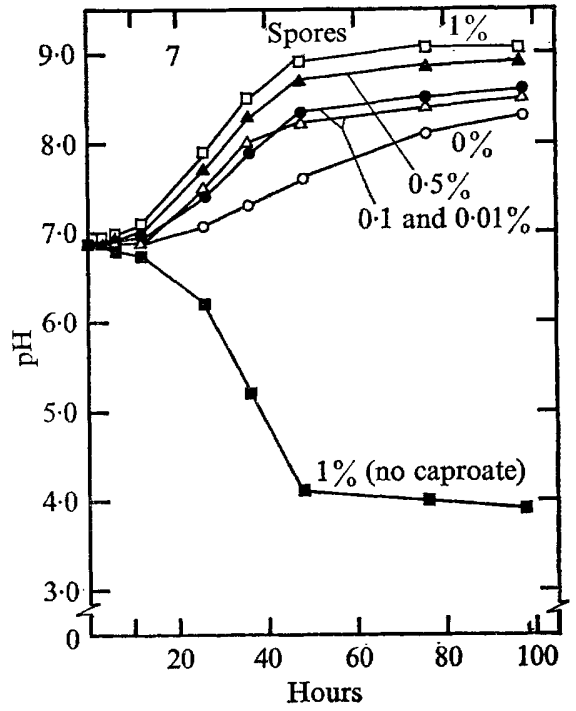

Fig. 7

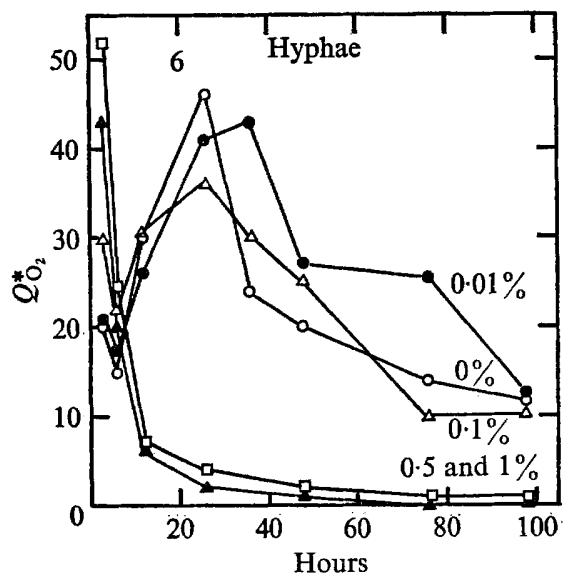

Fig. 6

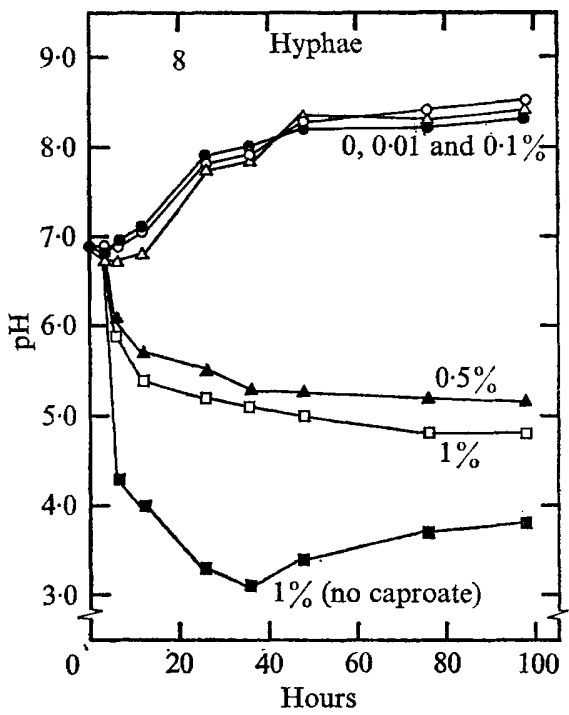

Fig. 8

Fig. 5 to 8. Effect of glucose concentration on respiratory activity (Fig. 5,6) and $\mathrm{pH}$ values (Fig. 7,8 ) of spore and hyphal cultures of Aspergillus niger containing $0.5 \%$ caproate. No glucose, $\mathrm{O}-\mathrm{O} ; 0.01 \%$ glucose, $-0 ; 0.1 \%$ glucose, $\triangle-\triangle ; 0.5 \%$ glucose, $\boldsymbol{\Delta}-\boldsymbol{\Delta}$; $\mathrm{I} \cdot \mathrm{O} \%$ glucose, $\square-\square$; cultures without caproate but containing $\mathrm{I} \cdot 0 \%$ glucose,

\section{DISCUSSION}

Several investigators (Gehrig \& Knight, 1958; Franke et al. 1962; Lawrence, 1966) have maintained that only ungerminated spores of filamentous fungi can convert fatty acids to methyl ketones. My studies have shown (Fig. I) that ungerminated conidia of Aspergillus niger convert caproic acid to 2-pentanone at an extremely low rate, if at all. Moreover, the course of ketone production by conidia was directly related to the course of germination and formation of young hyphae. This agrees with 
the report of Franke, Platzeck \& Eichorn (196I) that the $\beta$-keto acid decarboxylase activity of $A$. niger was greatest in young mycelia.

The production of 2-pentanone from caproic acid by vegetative hyphae of Aspergillus niger is contrary to the report of Franke et al. (1962), which stated that vegetative hyphae of this organism were unable to form methyl ketones from fatty acids. However, good ketone production by spore preparations depends upon a supplementary growth substrate such as glucose, as found in the present study (Fig. I) and by other workers

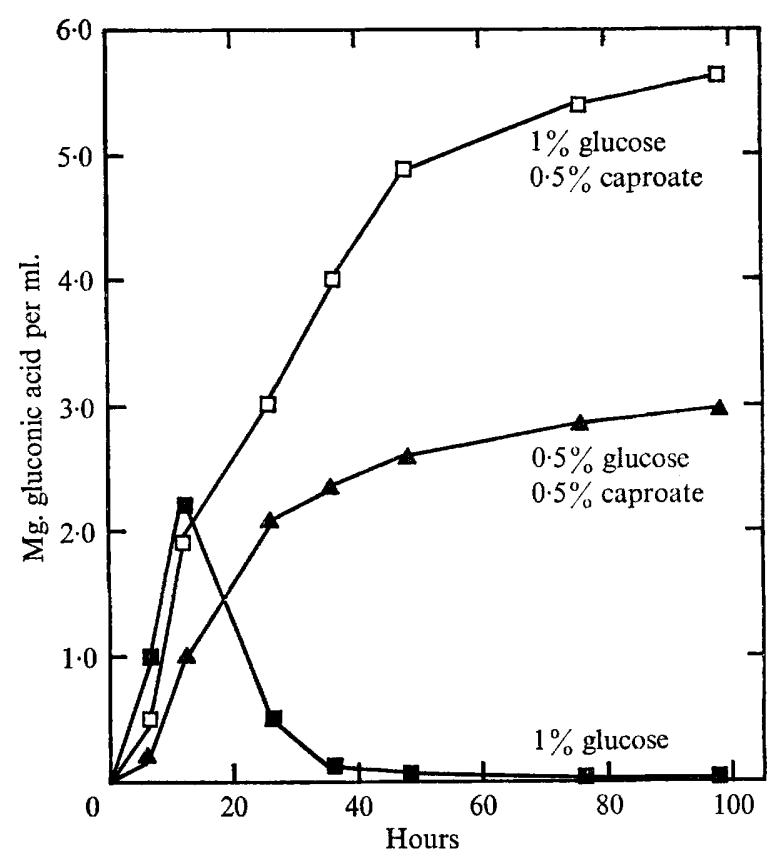

Fig. 9. Effect of caproate $(0.5 \%)$ on gluconic acid production from glucose by hyphal preparations of Aspergillus niger. One $\%$ glucose alone, $\square-\square ; 0.5 \%$ glucose $+0.5 \%$ caproate, $\Delta-\Delta ; \mathbf{I} \cdot 0 \%$ glucose $+0.5 \%$ caproate, $\square-\square$.

including Franke et al (1962) and Lawrence (1966). Under these conditions, ketone production by vegetative hyphae is practically nil (Fig. 2). It is therefore not surprising that reports of the inability of vegetative hyphae to form ketones from fatty acids have appeared, since the hyphae were usually tested under conditions for maximal ketone production by spore preparations.

The suppression of the conversion of caproate to 2-pentanone in vegetative hyphae by glucose (Fig. 2) may be caused by the oxidation of glucose to gluconic acid with the consequent fall in $\mathrm{pH}$, since this would result in an increased concentration of undissociated as compared with dissociated caproic acid, and as shown by Lewis \& Johnson (1967), high concentrations of undissociated caproic acid can inhibit terminal respiratory enzymes, and thus fatty acid oxidation. Glucose oxidase did not, however, appear to be inhibited since glucose disappearance and gluconic acid production continued even though fatty acid oxidation and ketone formation had ceased.

Activation of fatty acid oxidation in Aspergillus niger spores by glucose (Fig. I) is consistent with the report of Lawrence (1965). Very little carbon or energy could have 
been derived from fatty acid oxidation by spores, since caproate was converted almost exclusively to 2-pentanone. Increases in $\mathrm{pH}$ and $Q_{\mathrm{o}_{2}}$ values with increasing glucose concentrations indicated that spores and young mycelia oxidized glucose completely. Gluconic acid never accumulated in caproate containing cultures of germinating spores, and only small amounts of other organic acids were detected. These results are consistent with the report by Bhatnager \& Krishnan (1960) that activated spores and vegetative hyphae of $A$. niger contain different enzymes.

Moyer, Umberger \& Stubbs (1940) found that gluconic acid production by Aspergillus niger was affected by the $\mathrm{pH}$ value of the culture medium. At $\mathrm{pH}$ values above 6.5, glucose was converted almost exclusively to gluconic acid, whereas citric acid was the predominant acid produced at $\mathrm{pH}$ values below $3^{\circ} \mathrm{O}$. Butkewitsch (1924) pointed out that gluconic and citric acid formation proceeded sequentially in fungal cultures with initial $\mathrm{pH}$ values near neutrality. Gluconic acid was produced when the $\mathrm{pH}$ value was above $6 \cdot 5$, but as the $\mathrm{pH}$ value fell below $6 \cdot 5$ citric acid accumulated. In the present study this occurred in vegetative hyphal cultures with $\mathrm{I} .0 \%$ glucose and no caproate but not when $0.5 \%$ caproate was present in addition to glucose. Gluconate production then continued after the $\mathrm{pH}$ value fell below $6 \cdot 5$ (Fig. 8,9 ).

Ehrlich \& Lewis ( 1968$)$ found that fatty acids $\left(\mathrm{C}_{3}-\mathrm{C}_{13}\right)$ did not inhibit glucose oxidase from Aspergillus niger although succinic dehydrogenase activity was completely inhibited and many of the fatty acids stimulated glucose oxidase activity, the effect being maximal at $\mathrm{pH}$ values below $6 \cdot 5$. Selective inhibition of enzymes involved in glucose dissimilation by free fatty acids under conditions where gluconeogenic enzymes were not affected had been reported for bacterial (Ferdinandus \& Clark, 1969) and animal (Weber, Convery, Lea \& Stamm, I966) systems.

The present study shows that caproic acid can alter the mode of glucose catabolism in Aspergillus niger; and since the lipid fraction of $A$. niger may contain high concentrations of free fatty acids (Bernhauer \& Posselt, 1937; Cochrane, I958), these compounds may be of importance for the control of metabolic pathways in this fungus.

This investigation was supported by grant D-I75 from The Robert A. Welch Foundation, Houston, Texas. The technical assistance of $\mathrm{Mr}$ W. S. Coggin is acknowledged.

\section{REFERENCES}

Acklin, O. (1929). Zur Biochemie des Penicillium glaucum. I. Ein Beitrag zum Problem der Methylketonbildung aus Triglyceriden bzw. Fettsäuren im Stoffwechsel des Schimmelpilzes. II. Die Bildung der Methylketone. Biochemische Zeitschrift 204, 253-274.

Bernhauer, K. \& Posselt, G. (1937). Über Schimmelpilzlipoide. II. Die Zusammensetzung eines Aspergillus-niger-Fettes. Biochemische Zeitschrift 294, 215-220.

Bhatnagar, G. M. \& Krishnan, P. S. (I960). Enzymatic studies on the spores of Aspergillus niger. III. Enzymes of Embden-Meyerhof-Parnas pathway in germinating spores of Aspergillus niger. Archiv für Mikrobiologie 37, 2 I I-2I4.

Butkewitsch, W. (1924). Über die Bildung der Glucon-und Citronen-säure in den Pilzkulturen auf Zucker. Biochemische Zeitschrift 154, I77-190.

Cochrane, V. W. (1958). Physiology of Fungi. New York: John Wiley.

CONWAY, E. J. \& DoWNEY, M. (1950). An outer metabolic region of the yeast cell. Biochemical Journal 47, 347-355.

EhrLICH, R. T. \& Lewis, H. L. (1968). Regulation of glucose metabolism in Aspergillus niger by fatty acids. Bacteriological Proceedings, 142. 
Ferdinandus, J. \& Clark, J. B. (I969). Selective inhibition of bacterial enzymes by free fatty acids. Journal of Bacteriology 98, I IO9-I II3.

Fisher, R. B., Parsons, D. S. \& Holmes, R. (I949). Quantitative paper chromatography. Nature, London $\mathrm{I64}, \mathrm{I} 83$.

Folin, O. \& Malmros, H. (1929). Improved micro method for the determination of blood sugar. American Journal of Physiology 90, 347-348.

Franke, W. \& HeINEN, W. (I958). Zur Kenntnis des Fettsäureabbaus durch Schimmelpilze. I. Über die Methylketonbildung der Schimmelpilze. Archiv für Mikrobiologie 3I, 50-55.

Franke, W., Platzeck, A. \& Eichorn, A. (196r). Zur Kenntnis des Fettsäureabbaus durch Schimmelpilze. III. Über eine Decarboxylase der mittleren Beta-ketomonocarbonsäuren (Beta-ketolaurat-decarboxylase). Archiv für Mikrobiologie 40, 73-93.

Franke, W., Platzeck, A. \& Eichorn, G. (1962). Zur Kenntnis des Fettsäureabbaus durch Schimmelpilze. IV. Versuche zum weiteren Umsatz der Methylketone. Archiv für Mikrobiologie 4I, I54-I68.

GeHrig, R. F. \& KNIGHT, S. C. (1958). Formation of ketones from fatty acids by spores of Penicillium roqueforti. Nature, London $\mathbf{1 8 2}$, 1237.

GeHRIG, R. F. \& KNIGHT, S. G. (I961). Formation of 2-heptanone from caprylic acid by spores of various filamentous fungi. Nature, London 192, I 185 .

Koepsell, H. J., Stodola, F. H. \& Sharpe, C. S. (1952). Production of $\alpha$-ketoglutarate in glucose oxidation by Pseudomonas fluorescens. Journal of the American Chemical Society 74, 5I42-5144.

LAWRENCE, R. C. (1965). Activation of spores of Penicillium roqueforti. Nature, London 208, 801-803.

LAWRENCE, R. C. (1966). The oxidation of fatty acids by spores of Penicillium roqueforti. Journal of General Microbiology 44, 393-405.

LAWRENCE, R. C. (1967). The metabolism of triglycerides by spores of Penicillium roqueforti. Journal of General Microbiology 46, 65-76.

Lewis, H. L. \& Johnson, G. T. (1967). Growth and oxygen uptake responses of Cunninghamella echinulata on even chain fatty acids. Mycologia $59,878-887$.

Moyer, A. J., Umberger, E. J. \& StubBs, J. J. (I940). Fermentation of concentrated solutions of glucose to gluconic acid: Improved process. Industrial Engineering Chemistry 32, I379-1383.

STÄRKLE, M. (1924). Die Methylketone im oxydativen Abbau einiger Triglyceride (bzw. Fettsäuren) durch Schimmelpilze unter Berücksichtigung der besondern Ranzidität des Kokosfettes. I. Die Bedeutung der Methylketone im Biochemismus der Butterranzidität. II. Über die Entstehung und Bedeutung der Methylketone als Aromastoffe in Roquefortkäse. Biochemische Zeitschrift 15r, 37 I-4I5.

Stokoe, W. N. (I928). The rancidity of coconut oil produced by mould action. Biochemical Journal 22, 80-93.

ThaLER, H. \& STÄHLIN, I. (1949). Zur Chemie der Ketonranzigkeit. IV. Die Identifizierung der Methylketone. Biochemische Zeitschrift 320, 84-86.

Umbreit, W. W., Burris, R. H. \& Stauffer, J. F. (I964). Manometric Techniques, 4th edn. Minneapolis, Minnesota: Burgess Publishing Co.

Weber, G., Convery, H. J. H., LeA, M. \& Stamm, N. B. (I966). Feedback inhibition of key glycolytic enzymes in liver by action of free fatty acids. Science, New York 154, 1357-1360. 